\title{
Plant architecture influences gall abundance in a tropical montane plant species
}

\author{
Maria Gabriela Boaventura' ${ }^{1}$, Cássio Cardoso Pereira' ${ }^{1}$ (1) and Tatiana Cornelissen²* (1)
}

Received: February 2, 2018

Accepted: July 23, 2018

\begin{abstract}
Sessile and host-specific herbivores, such as gall-inducing insects, are usually patchily distributed within the populations of their host plants, and it has been suggested that both inter- and intra-plant variation affect gall abundance, distribution and survivorship. Variation in plant traits, such as size and architecture, has been previously demonstrated as a determinant of gall distribution. We examined the influence of architectural complexity of the tropical plant Galianthe brasiliensis (Rubiaceae) on the abundance of the stem-galler Lopesia sp. (Diptera, Cecidomyiidae) along an elevation gradient where both insect and plant were distributed. A total of 120 plants were sampled along the gradient and more than 580 galls were counted, while plant architectural complexity was determined by a combination of height and branch ramification. Increased elevation did not influence plant complexity nor gall abundance (both $\mathrm{P}>0.05)$, but plant architectural complexity explained more than $60 \%$ of the variation in gall abundance along the gradient $\left(\mathrm{R}^{2}=0.62, \mathrm{P}<0.001\right)$. We suggest that the greater availability of meristematic tissues in more architecturally complex plants explains the results found, as this is a key resource for gall occurrence and establishment.
\end{abstract}

Keywords: elevation gradient, galls, insects, plant architecture hypothesis, plant quality

Plant selection by insect herbivores encompasses choices regarding plant physical and chemical characteristics that ultimately influence insect population dynamics and community organization. It has been long recognized that plant traits influence herbivore dynamics, distribution and abundance (see Price 1997; Cornelissen \& Stiling 2008) and intra-specific variation in plant size, chemistry and apparency can have profound effects on herbivore selection and herbivory levels experienced by host plants. Top-down effects via pressure exerted by natural enemies also have the potential

Sessile and host-specific herbivores, such as gallinducing insects, are usually patchily distributed within the populations of their host plants, and it has been suggested that both bottom-up and top-down effects explain variation in gall abundance (Araújo et al. 2006; 2013; Barbosa \& Fernandes 2014), distribution (Lara et al. 2008; Bergamini et al. 2017) and survivorship (Hosaka et al. 2009). Variation

1 Programa de Pós-Graduação em Ecologia, Universidade Federal de São João del-Rei, 36307-352, São João del-Rei, MG, Brazil

2 Laboratório de Ecologia Vegetal e Interações, Departamento de Ciências Naturais, Universidade Federal de São João del-Rei, 36307-352,

São João del-Rei, MG, Brazil

* Corresponding author: tatiana@ufsj.edu.br 
in plant patch size (The resource concentration hypothesis, Root 1973) as well as individual variation in plant traits such as size and architecture (The plant architecture hypothesis, Lawton 1983) have been previously demonstrated as bottom-up factors that are determinants of insect gall distribution (Strong et al. 1984). Plant architecture includes several different traits such as size, growth form, number of branches and patterns of branch organization, as well as combinations of these traits.

Plant architecture complexity may represent a more heterogeneous habitat to insects as they increase resource spatial distribution and the abundance of apical meristems. Previous studies have demonstrated a positive relationship between plant architecture and insect richness or abundance (e.g., Araújo et al. 2006; Espírito-Santo et al. 2012). Gallinducing insects, for example, have both the capacity to use plant architecture as a proxy for plant quality (Price 1991) and enemy-free space (Araújo et al. 2006), as well as the ability to alter plant architecture (Crutsinger et al. 2008). For tropical gall-inducing insects, Espírito-Santo et al. (2007) demonstrated that, for 17 species of the genus Baccharis (Asteraceae), the availability of fourth-level shoots - which indicates the availability of apical meristems for gall formation- influenced gall richness and abundance.

Compared to other bottom-up effects influencing herbivore selection between and within plants - such as secondary chemistry and structural defenses - plant architecture has received much less attention (Rudgers \& Whitney 2006) and most of the studies so far have been conducted for temperate plants (see review in Lawton 1983; Denno 2012). Here, we provided data on the effects of plant architecture on a Neotropical gall-inducing insect along an altitudinal gradient in the Atlantic Forest. We tested the following hypotheses: 1) plant architecture changes along an altitudinal gradient, with decreased complexity as altitude increases, 2) gall abundance decreases with increasing altitude due to the negative effects of climate harshness as altitude increases and 3) gall abundance is positively related to plant architecture, as predicted by the Plant Architecture Hypothesis.

Galianthe brasiliensis (Spreng.) (Rubiaceae) is a small shrubby species, between 30 and $100 \mathrm{~cm}$ in height (Forzza 2010). Its abundant leaves are elliptical and it exhibits a woody, extremely ramified main shoot (Fig. 1). The species is distributed between Mexico and Argentina and it usually grows associated to tropical, humid forests in montane habitats. Few insect herbivores attack its leaves (pers obsv.), but the plants are heavily colonized by the gall midge Lopesia sp. (Diptera, Cecidomyiidae). Galls are elliptical, brown, with one chamber and one larva per chamber and are distributed all over the shoots (Fig. 1).

This study was conducted at the RPPN Alto Montana, a reserve along a tropical mountain in southeastern Brazil, in a region covered by Atlantic Forest (22 $21^{\prime} 55^{\prime \prime} S 44^{\circ} 48^{\prime} 32^{\prime \prime} \mathrm{W}$ ). Data were sampled along an altitudinal gradient spawning

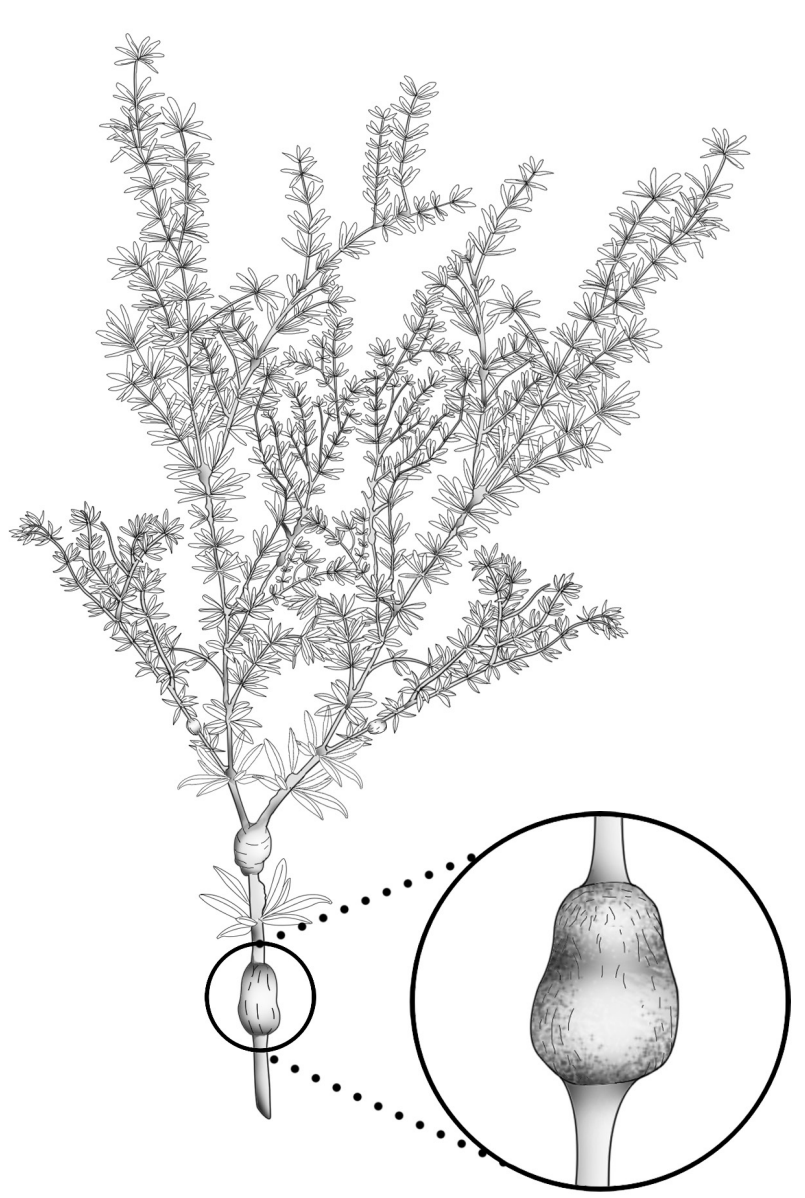

Figure 1. Schematic representation of Galianthe brasiliensis (Rubiaceae) showing its shoots, leaves and a Lopesia sp. gall (in detail, in the main stem).

$700 \mathrm{~m}$, from 1.400 to $2.100 \mathrm{~m}$ above sea level, totaling eight altitudinal points spaced at every $100 \mathrm{~m}$. Data were collected in November 2016, during the wet season, in a population of $G$. brasiliensis distributed along the gradient.

Sampling points at every altitudinal point were determined with a GPS with altimeter and at each point 15 individuals of $G$. brasiliensis were marked ( $\mathrm{n}=120$ plants sampled along the gradient). Plants were at least $10 \mathrm{~m}$ from each other to increase independence. In the field we determined plant height $(\mathrm{cm})$ and all plants were removed, taken to the laboratory and number of galls was counted in all shoots. Architectural complexity was determined by counting the number of ramifications from the primary shoot (Fig. S1 in supplementary material), according to the point of origin.

Data collected for the 15 plants were averaged and used as replicates for each altitudinal point. To estimate variation in architectural complexity of $G$. brasiliensis along the altitudinal gradient, the index IAC (Index of Architectural Complexity) adapted from Espirito-Santo et al (2007), was calculated as $\left[I A C=h^{*}(b 2+b 3+b 4)\right]$, where $h=$ height, $b=$ branch and the numbers in parentheses represent the order of the ramifications. 
Generalized linear models (GLMs) were used to examine the relationship between IAC and gall abundance with altitude, using altitudinal points as the independent variable. To examine whether plant architecture influenced gall abundance, a Generalized linear mixed model (GLMM) was built with gall abundance as the dependent variable, architecture as the fixed variable and altitude as a random variable. Binomial distribution corrected for overdispersion was used and followed by residual analysis and error distribution.

We sampled a total of 120 plants and 587 galls in Galianthe brasiliensis along the altitudinal gradient. The number of branch ramifications varied between 3 and 11, but most plants ( $66 \%$ of the individuals sampled) exhibited between four and five ramifications. Plants and galls were distributed all along the altitudinal gradient and were registered in each altitudinal point.

Variation in altitude did not influence gall abundance $\left(\mathrm{R}^{2}=0.23, \mathrm{P}=0.232\right)$ or architectural complexity of $G$. brasiliensis $\left(\mathrm{R}^{2}=0.104, \mathrm{P}=0.807\right)$. Gall abundance, however, was strongly influenced by plant architectural complexity $\left(\mathrm{R}^{2}=0.62, \mathrm{~F}_{1,6}=31.38, \mathrm{P}<0.001\right.$, Fig. 2). Because plant height alone did not change with altitude $\left(\mathrm{F}_{7,112}=1.69, \mathrm{P}=0.119\right)$, we suggest that changes in plant height combined with the complexity of shoots in Galianthe influence gall inducer selection and occurrence in this plant.

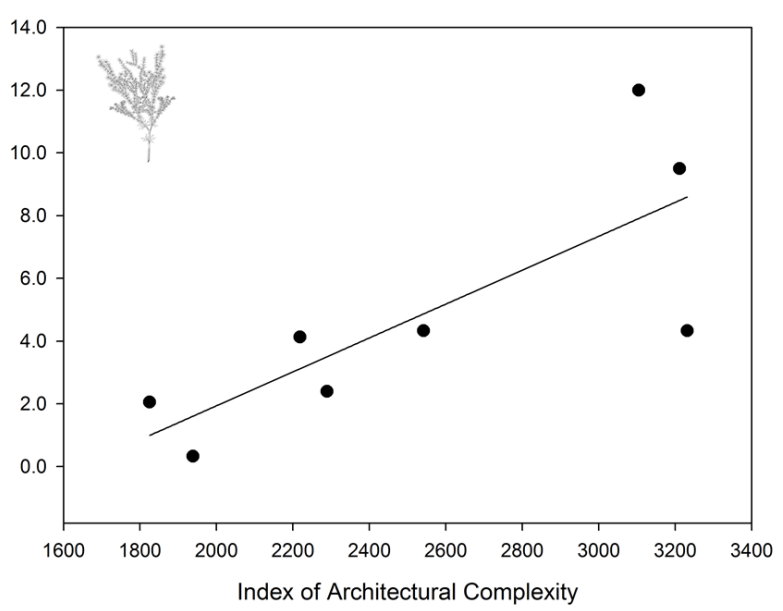

Figure 2. Relationship between gall abundance and architectural complexity of the plant Galianthe brasiliensis (Rubiaceae) along an altitudinal gradient in a remnant of Atlantic Forest in Brazil.

For insects, both direct and indirect effects of plant architecture have been suggested as factors shaping host plant selection (Marquis et al. 2002). Our results have shown that more complex plants exhibit more galls, although gall abundance and plant complexity do not vary along the altitudinal gradient, indicating that plant morphological features might be more important to galling insects selection and occurrence.

Galianthe brasiliensis was distributed all along the altitudinal gradient in the studied area, forming a continuous patch from 1.400 to 2.100 m.a.s.l. Although at some pojnts along the gradient plants were visibly different in terms of size and/or complexity (pers obsv), altitude itself did not influence plant architecture. Lopesia galls were also found all along the gradient and variation in altitude alone did not influence gall abundance. The abundance of the hosts, and therefore the abundance of resources, might have influenced the occurrence and establishment of this gall-inducing insect, as suggested by the plant density hypothesis (CuevasReyes et al. 2004). This hypothesis predicts that because gall-inducing insects are species-specific, the abundance of hosts influences the abundance of galls (Cuevas-Reyes et al. 2004; Carneiro et al. 2014), as found in our study system. Some previous studies with gall-inducing insects in the Atlantic forest have suggested that Rubiaceae is a host for several galls (Lebel et al. 2008; Maia et al. 2014) although only Lopesia galls were found in Galianthe plants all along the gradient. The density of Galianthe plants was not measured in the field due to the logistical difficulties associated to sample along the elevation gradient, but the plants here evaluated were sampled on the open trail along the mountain and patch size was similar all along the altitudinal gradient, as plants were limited on both sides of the trail by open and sunny areas.

Besides host occurrence and distribution, gall abundance was strongly influenced by plant architectural complexity. Although there was some variation in the number of ramifications in Galianthe plants - with some individuals exhibiting up to 11-order branches - plants with increased height combined with increased branch complexity exhibited more galls. More than $60 \%$ of variation in gall abundance was explained by variation in plant complexity, indicating the importance of this bottom-up factor in shaping the population dynamics of this gall-inducing insect along a montane tropical forest. According to the Plant Architecture Hypothesis (Lawton 1983), plants that are structurally more complex are better hosts to insects, increasing insect richness and/or abundance. Several mechanisms have been proposed to explain this positive relationship between host plant complexity and insect load, and some of them include a greater abundance of microhabitats to be colonized, greater abundance of apical meristems for gall induction and also enemy-free space. For the also tropical species Baccharis pseudomyriocephala (Asteraceae), Araújo et al. (2006) found a positive relationship between gall richness and abundance and host complexity. In our study, variation in plant height combined with variation in the number of branch ramifications might have created habitats for gall occurrence and colonization, leading to more galls in more complex plants. Another possibility is that gall-inducing insects themselves change plant architecture as galls develop, being therefore responsible for plant branching after galls are initiated. In a study with the temperate plant Solidago altissima and the rosette gall-midge Rhopalomyia solidaginis, it has been shown that galling by insects actually 
alter the architectural complexity in this plant and galled plants exhibited almost $60 \%$ more biomass than ungalled plants, due to the branching and leaf accumulation caused by gall formation. We believe this causal effect might not be the case in our study system, as Lopesia galls are induced in the stems and we have found several ungalled plants along the altitudinal gradient with great architectural complexity, indicating that there is some level of selection amongst the available hosts. However, the causal and consequential effects of architecture on galls are still unexplored for tropical plant species with wide distribution and wide variation in morphological aspects (e.g., height and branch ramification) and it deserves further attention to separate the effects of host morphology on gall selection and occurrence.

Plants with higher architectural complexity might exhibit greater abundance and/or resource quality for herbivores (Price 1997). Increased height as well as variation in the patterns of branching - parameters commonly used and also combined to determine plant architectural complexity (see Gonçalves-Alvim et al 1999; Marquis et al. 2002; EspíritoSanto et al. 2007) - are closely related to the amount of active meristems in a plant (Larson \& Whitham 1997; Carneiro et al. 2014), which directly influences gall richness and abundance. The presence of active meristems facilitates the morphological alterations caused by gall formation such as cell hypertrophy and hyperplasia and previous studies have shown that galls cannot be initiated in already developed tissues (Fernandes \& Santos 2014). In our studied system, architectural complexity did not change with altitude, but positively and strongly influenced the abundance of stem galls in Galianthe, indicating that architectural complexity might be a good proxy for plant resources for gall-inducing insects.

Contrary to our expectations, however, architectural complexity and gall abundance did not decrease with increased altitude. Previous studies have found an inverse relationship between gall richness and/or abundance and altitude (e.g., Fernandes \& Price 1988; 1991; 1992; Blanche \& Ludwig 2001; Carneiro et al. 2014) as well as altitude and architectural complexity (Homeier et al. 2010). Classical studies as those of Fernandes \& Price (1988; 1991; 1992) suggest that gall abundance usually decrease with altitude due to the sensitivity of gall-inducing insects to changes in humidity and temperature associated to increased altitude. More recent studies such as Carneiro et al. (2014) have suggested, however, that altitude might influence gall abundance only in xeric habitats, as the morphological structure created by the gall actually protects the growing larvae against climatic harsh and natural enemies (Price et al. 1987; Fernandes \& Price 1991; Carneiro et al. 2014).

Our results have demonstrated that the occurrence of the host plant Galianthe brasiliensis all along a tropical montane gradient and its architectural complexity explained the variation in the abundance of the stem galler Lopesia sp., indicating the importance of this bottom-up factor as a determinant of gall occurrence and abundance, possibly due to the greater availability of meristematic tissues in more complex plants and its influence on gall development.

\section{Acknowledgements}

This study was part of the graduate course "Field Ecology" from the Graduate Programa in Ecology of UFSJ. The authors thank UFSJ, PROPE/UFSJ, CAPES, FAPEMIG, CNPq (grant \#307210/2016-2) for financial support and RPPN Alto Montana for logistical support. Illustrations of the plant and gall-inducing insect were made by Scientific Ink ${ }^{\circledR}$.

\section{References}

Araújo APA, Paula JD, Carneiro MAA, Schoereder JH. 2006. Effects of host plant architecture on colonization by galling insects. Austral Ecology 31: 343-348.

Araújo WS, Scareli-Santos C, Guilherme FAG, Cuevas-Reyes P. 2013. Comparing galling insect richness among Neotropical savannas: effects of plant richness, vegetation structure and super-host presence. Biodiversity and Conservation 22: 1083-1094.

Barbosa M, Fernandes GW. 2014. Botom-up effects on gall distribution. In: Fernandes GW, Santos JC. (eds.) Neotropical insect galls. Dordrecht, Springer. p. 99-113.

Bergamini BAR, Bergamini LL, Santos BB, Araujo WS. 2017. Distribution of insect galls in xeric and mesic habitats of Floresta Nacional de Silvânia, Brasil. Iheringia, Série Zoologia 107: e2017042. doi:10.1590/1678$4766 \mathrm{e} 2017042$

Blanche KR, Ludwig JA. 2001. Species richness of gall-inducing insects and host plants along an altitudinal gradient in Big Bend National Park, Texas. The American Midland Naturalist 145: 219-232.

Carneiro MAA, Coelho MS, Fernandes GW. 2014. Galls in Brazilian mountains: new reports and perspectives. In: Fernandes GW, Santos JC. (eds.) Neotropical Insect Galls. Dordrecht, Springer. p. 273-293.

Cornelissen T, Stiling P. 2008. Clumped distribution of oak leaf miners between and within plants. Basic and Applied Ecology 9: 67-77.

Crutsinger GM, Habenicht MN, Classen AT, Schweitzer JA, Sanders NJ. 2008. Galling by Rhopalomyia solidaginis alters Solidago altissima architecture and litter nutrient dynamics in an old-field ecosystem. Plant Soil 303: 95-103.

Cuevas-Reyes P, Quesada M, Hanson P, Dirzo R, Oyama K. 2004. Diversity of gall-inducing insects in a Mexican tropical dry forest: the importance of plant species richness, life-forms, host plant age and plant density. Journal of Ecology 92: 707-716.

Denno RF, McClure MS. 2012. Variable plants and herbivores in natural and managed systems. 1st. edn. New York, Academic Press.

Espírito-Santo MM, Neves FS, Andrade-Neto FR, Fernandes GW. 2007. Plant architecture and meristem dynamics as the mechanisms determining the diversity of gall-inducing insects. Oecologia 153: 353-364.

Espírito-Santo MM, Neves FS, Fernandes GW, Silva JO. 2012. Plant phenology and absence of sex-biased gall attack on three species of Baccharis. PLOS ONE 7: e46896. doi: 10.1371/journal.pone.0046896

Fernandes GW, Price PW. 1988. Biographical gradients in galling species richness: test of hypotheses. Oecologia 76: 161-167.

Fernandes GW, Price PW. 1991. Comparisons of tropical and temperate galling species richness: the roles of environmental harshness and plant nutrient status. In: Price PW, Lewinsohn TM, Benson WW. (eds.) Plant-animal interactions: evolutionary ecology in tropical and temperate regions. New York, Wiley. p. 91-115. 
Fernandes GW, Price PW. 1992. The adaptive significance of insect gall distribution: survivorship of species in xeric and mesic habitats. Oecologia 90: 14-20.

Fernandes GW, Santos JC. 2014. Neotropical Insect galls. 1st. edn. Dordrecht, Springer.

Forzza RC. 2010. Lista de Espécies da Flora do Brasil. http://floradobrasil. jbrj.gov.br. 20 Dec. 2017.

Gonçalves-Alvim SJ, Faria ML, Fernandes GW. 1999. Relationships between four neotropical species of galling insects and shoot vigor. Anais da Sociedade Entomológica do Brasil 28: 147- 55.

Homeier J, Breckle SW, Günter S, Rollenbeck RT, Leuschner C. 2010. Tree diversity, forest structure and productivity along altitudinal and topographical gradients in a species rich ecuadorian Montane Rain Forest. Biotropica 42: 140-148.

Hosaka T, Takagi S, Okuda T. 2009. A preliminary survey of insect galls on dipterocarps in a lowland rainforest at Pasoh, Peninsular Malaysia. Tropics 18: 93-102.

Lara DP, Oliveira LA, Azevedo IFP, et al. 2008. Relationship between host plant architecture and gall abundance and survival. Revista Brasileira de Entomologia 52: 78-81.

Larson KC, Whitham TG. 1997. Competition between gall aphids and natural plant sinks: plant architecture affects resistance to galling. Oecologia 109: 1432-1439.

Lawton JH. 1983. Plant architecture and the diversity of phytophagous insects. Annual Review of Entomology 28: 23-29.
Lebel P, Silva SCL, Cortez JA. 2008. Galling insect distribution on Psychotria barbiflora (Rubiaceae) in a fragment of Atlantic Forest. Ecotropicos 21: 46-53.

Maia VC, Cardoso LJT, Braga JMA. 2014. Insect galls from Atlantic Forest areas of Santa Teresa, Espírito Santo, Brazil: characterization and occurrence. Boletim do Museu de Biologia Mello Leitão 33: 47-129.

Marquis JR, Lill JT, Piccinni A. 2002. Effect of plant architecture on colonization and damage by leaf-tying caterpillars of Quercus alba. Oikos 99: 531-537.

Price PW. 1991. The plant vigor hypotheses and herbivore attack. Oikos 62: 244-251.

Price PW. 1997. Insect ecology. 3rd. edn. New York, Wiley.

Price PW, Waring GL, Fernandes GW. 1987. Hypotheses on the adaptive nature of galls. Proceedings of the Entomological Society of Washington 88:361-363.

Root RR. 1973. Organization of a plant-arthropod association in simple and diverse habitats: the fauna of collards (Brassica oleraceae). Ecological Monographs 43: 95-124.

Rudgers JA, Whitney KD. 2006. Interactions between insect herbivores and a plant architectural dimorphism. Journal of Ecology 94: 1249-1260.

Strong DR, Lawton JH, Southwood R. 1984. Insects on plants: community patterns and mechanisms. 1st. edn. Oxford, Blackwell Scientific Publications. 